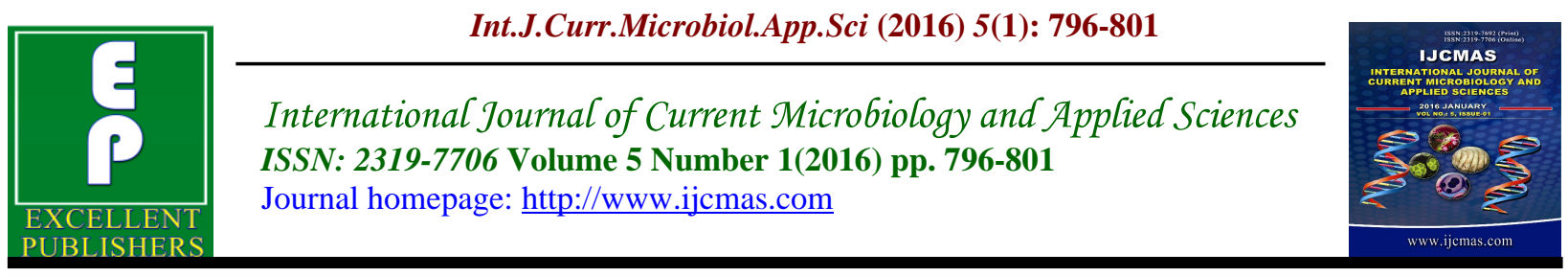

Original Research Article

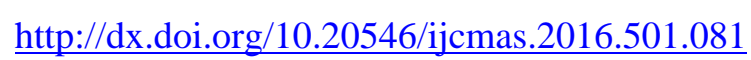

\title{
Incidence of Broad Spectrum Resistance in $E$.coli Isolated from Zoborodo sold in Samaru, Zaria, Nigeria
}

\author{
O. Adenaike ${ }^{1}$, O.S. Olonitola ${ }^{2}$, J.B. Ameh ${ }^{2}$ and C.M.Z. Whong ${ }^{2}$ \\ ${ }^{1}$ Department of Biological Sciences, Oduduwa University Ipetumodu, Nigeria \\ ${ }^{2}$ Department of Microbiology, Ahmadu Bello University, Zaria, Nigeria
}

*Corresponding author

\begin{abstract}
A B S T R A C T
Keywords

Ampicillin, Antibiogram, Cephalothin, Zoborodo

Article Info

Accepted:

22 December 2015

Available Online:

10 January 2016

Antibiogram of twenty six (26) E.coli strains obtained from a hundred and fifty satchets of zoborodo drink against eight antibiotics were carried out to investigate incidence of broad spectrum resistance. Broad spectrum resistance was taken as resistance to ampicillin and cephalothin. Resistance of 69 and $92 \%$ of the E.coli to ampicillin and cephalothin respectively was obtained, amounting to $92 \%$ broad spectrum resistance. E.coli exhibiting single antibiotic resistance were all resistant to only cephalothin while all the multiple antibiotic resistance E.coli were resistant to both ampicillin and cephalothin. Measures should be taken to increase the hygienic conditions of zoborodo preparation.
\end{abstract}

\section{Introduction}

'Zoborodo' drink today has become popular, with much acceptance in Nigeria and commonly referred to as 'zobo'. It is prepared by boiling the dry calyces of Hibiscus sabdariffa in water for about 10-15 min from which the pigment or flavour embedded is extracted. After extraction the filtrate may be taken hot as tea but most times allowed to cool and packaged in plastic sachet containers or bottles then taken as a refreshing drink when chilled.

The sharp sour taste of the raw extract is usually sweetened with sugar cane or granulated sugar, pineapple, orange or other fruits depending on choice. The sweetness of 'zobo' drink does not last long due to spoilage by microbial activities (Nwachukwu et al., 2007). Economically, zobo is cheap and has been shown to be good source of natural carbohydrates, protein and vitamin $\mathrm{C}$ which constitute a major reason for consuming the soft drink by the increasing population (Braide et al., 2012). However, the greatest limitation for production of 'zobo' drink is the rapid deterioration of the drink. Its shell-life is approximately twenty-four hours following 
production if not refrigerated. Microorganisms associated with the dried calyx and the processing for the production of 'zobo' drink and other factors may contribute to its spoilage (Nwachukwu et al., 2007). Production and sale of 'zoborodo' is still at the local level. The low sanitary practice during production and sales accounts for the poor quality and a cause for concern (Ayo et al., 2004). The production process of 'zobo' is neither standardized nor mechanised. This allows proliferation of the associated micro-organisms which potentiates spoilage and the short shelf-life associated with this sorrel beverage. Some of these organisms have been found to pose serious health risks to consumers as they are associated with food spoilage and intoxication (Braide et al., 2012).

It has been reported that Gram negative bacteria account for approximately $69 \%$ of the cases of bacterial food borne disease. Members of the gram negative bacteria mostly $E$. coli are widely distributed in the environment. Contaminated food and water are the major sources by which the bacteria are spread. Selected strains can cause a wide variety of infections in hospitals and community setting. Escherichia coli therefore, is commonly used as surrogate indicator, its presence in food generally indicate direct and indirect fecal contamination. Bacterial gastrointestinal infections continue to cause illness and death and contribute to economic loss in most parts of the world, including highincome countries that have developed surveillance and control programs (Okonko et al., 2010).

In the past 60 years, antibiotics have been critical in the fight against infectious disease caused by bacteria and other microbes. Antimicrobial chemotherapy has been a leading cause for the dramatic rise of average life expectancy in the twentieth century. However, disease-causing microbes that have become resistant to antibiotic drug therapy are an increasing public health problem. One part of the problem is that bacteria and other microbes that cause infections are remarkably resilient and have developed several ways to resist antibiotics and other antimicrobial drugs (Christopher et al., 2013). Previous studies have shown that $E$. coli is highly resistant to ampicillin, cephalothin, tetracycline and trimethoprim sulfamethoxazole (Adenaike et al., 2013). The aim of this work is to investigate broad spectrum resistance (resistance to ampicillin or cephalothin) in Escherichia coli isolated from 'zoborodo' drink.

\section{Materials and Methods}

\section{Sample Collection, Identification and Characterisation}

A hundred and fifty samples of 'zoborodo' drinks in satchets were purchased from sellers in stores and markets within Ahmadu Bello University, Zaria main campus, Samaru and its environs. They were immediately transported to the laboratory for microbiological analysis. An amount $25 \mathrm{ml}$ of each 'zoborodo' sample was homogenized in $225 \mathrm{ml}$ of $1 \%$ buffered peptone water. The homogenate was preenriched by incubating for $18-24 \mathrm{hr}$ at $37^{\circ} \mathrm{C}$. Ten fold serial dilutions were prepared at the end of the enrichment using $1 \%$ buffered peptone water as diluent. Identification and characterisation were carried out using conventional methods and confirmed using Microgen Gram negative Identification kit (Adenaike et al., 2013).

\section{Antimicrobial Susceptibility Testing}

For susceptibility testing, E.coli strains were tested for their susceptibility to eight 
antimicrobial agents using the disk diffusion method on Mueller Hinton agar. The inocula were standardise by adjusting the turbidity of the culture to match that of 0.5 MacFarland standard from which $0.1 \mathrm{ml}$ of the cultures were plated on Mueller Hinton agar plates, and spread evenly using a sterile spreader (Adenaike et al., 2013).

This was allowed to dry for $5 \mathrm{~min}$ and antibiotic discs were dispensed on the surface of the media and incubated aerobically at $37^{\circ} \mathrm{C}$ for $18 \mathrm{~h}$. The following antibiotic discs; Ampicillin $10 \mu \mathrm{g}$, cephalothin $30 \mu \mathrm{g}$, Cefpodoxime $10 \mu \mathrm{g}$, Ceftriaxone $30 \mu \mathrm{g}$, Ciprofloxacin $5 \mu \mathrm{g}$, trimethoprim- sulfamethoxazole $25 \mu \mathrm{g}$, tetracycline $30 \mu \mathrm{g}$ and amikacin $30 \mu \mathrm{g}$ (Oxoid Ltd., Basingstoke, Hampshire, England) were placed gently and allowed to stand for 5minutes to diffuse. After incubation at $37^{\circ} \mathrm{C}$ for 24 hours the inhibition zone (in diameters) were measured and compared with CLSI zone diameter interpretative standard breakpoints (CLSI, 2008). Intermediate isolates were counted as resistant in all the agents tested (Christopher et al., 2013). E.coli ATCC 25922 was used as quality control.

\section{Results and Discussion}

Resistance profile of antibiotic susceptibility testing carried out in Plate 1 is shown in Fig. 1. Highest resistance was found in cephalothin and ampicillin with 92 and 69\% respectively. A high resistance is also found in tetracycline with $54 \%$ resistance. This is probably because tetracycline is one of the older drugs (Introduced in 1948). Surveillance data show that resistance in $E$. coli is consistently highest for antimicrobial agents that have been in use for a long time in human and veterinary medicine (Tadesse et al., 2012). Gaetti-Jardim et al. (2010) also states that resistance to tetracycline could be related to its extensive use in medicine, veterinary and dentistry. High percentage of broad resistance (92\%) [Fig. 2] indicates the need for newer and less competitive drugs. The single antibiotic resistance E.coli were resistant to only cephalothin while the phenotypes of the multiple antibiotic resistance were all resistant to both ampicillin and cephalothin. As such all the E.coli resistant to ampicillin were equally resistant to cephalothin (Table 1). Cephalothin, a prototype of first generation cephalosporins, are narrow spectrum drugs, which have their best activity against Grampositive pathogens except methicillinresistant S. aureus (MRSA), and are active against some Gram-negative organisms (Walsh, 2003). Increasing resistance in Gram-negative organisms is likely rendering cephalothin improper for therapy of infections caused by Gram-negative organisms.

Ampicillin on the other hand is a betalactam antibiotic. It has had increased resistance due to the ability of some bacteria to produce enzymes ( $\beta$-lactamase) which hydrolyses the $\beta$-lactam ring rendering the antibiotic inactive against the bacteria. This has led to the introduction of newer drugs with higher stability against $\beta$-lactamases. Up to $90 \%$ of ampicillin resistance in E.coli is due to the production of TEM-1 (Lim et $a l ., 2009)$. This enzyme is able to hydrolyze penicillins and early cephalosporins such as cephalothin and cephaloridine. TEM-type $\beta$ lactamases are most often found in $E$. coli and Klebsiella pneumonia and also in other species of Gram-negative bacteria with increasing frequency (Bradford, 2001).

There is no resistance to ciprofloxacin and Amikacin. Several studies have established that susceptibility to ciprofloxacin or other fluoroquinolones are quite high among Enterobacteriaceae (Hassan et al., 2011). 
Table.1 Resistance Pattern of E. coli Isolated from 'Zoborodo' Drink

\begin{tabular}{|c|c|c|c|c|}
\hline \multicolumn{2}{|c|}{$\begin{array}{l}\text { Single antibiotic } \\
\text { Resistance }\end{array}$} & \multicolumn{3}{|c|}{ Multiple antibiotic resistance } \\
\hline $\begin{array}{l}\text { Number } \\
\text { of isolates } \\
(\%) \text { in the } \\
\text { category }\end{array}$ & $\begin{array}{l}\text { Resistance } \\
\text { phenotype }\end{array}$ & $\begin{array}{l}\text { Number of } \\
\text { antibiotic } \\
\text { combinations }\end{array}$ & $\begin{array}{l}\text { Number of } \\
\text { isolates } \\
(\%) \text { with the } \\
\text { pattern }\end{array}$ & $\begin{array}{l}\text { Resistance } \\
\text { Phenotype }\end{array}$ \\
\hline $6(23)$ & $\mathrm{KF}$ & $\begin{array}{l}2 \\
3 \\
5\end{array}$ & $\begin{array}{l}2(8) \\
8(31) \\
2(8) \\
2(8) \\
4(8) \\
\end{array}$ & $\begin{array}{l}\text { AMP, KF } \\
\text { AMP, KF, TE } \\
\text { AMP, KF, CPD } \\
\text { AMP, KF, CPD, CRO, TE } \\
\text { AMP, KF, CPD, SXT, TE }\end{array}$ \\
\hline
\end{tabular}

Key: AMP-Ampicillin; KF- Cephalothin; CPD- Cefpodoxime; CRO-Ceftriaxone;

SXT- Sulphamethoxazole-trimethoprim (Co-trimethoprim); TE-Tetracycline

Fig.1 Resistance Profile of E. coli Isolated from 'Zoborodo' Drink

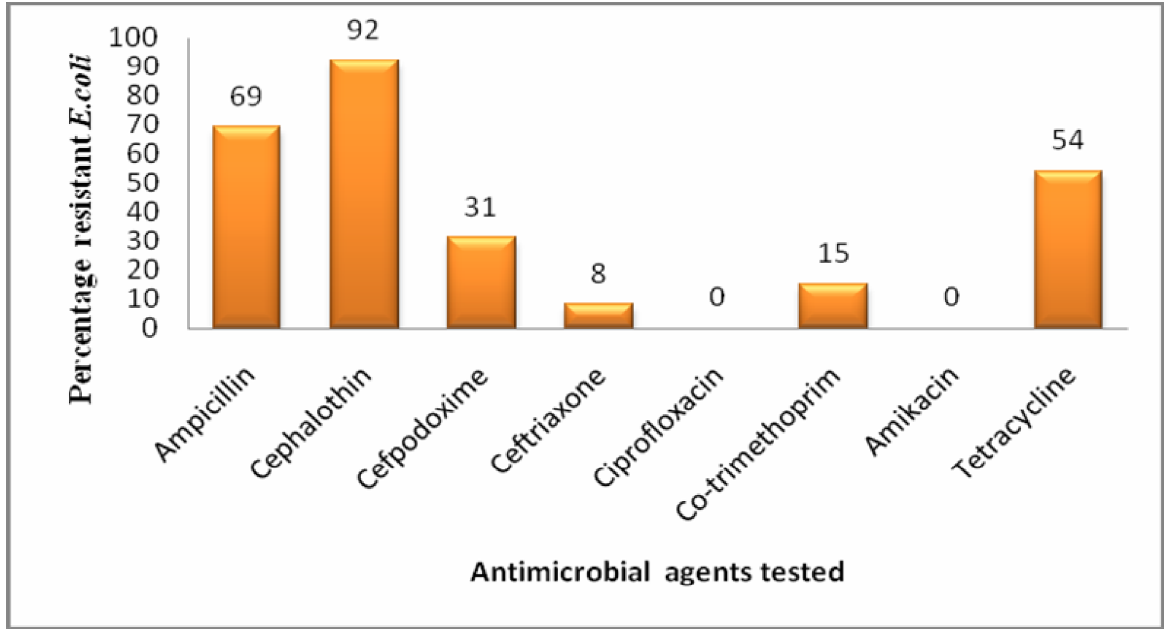

Fig.2 Broad Spectrum resistance

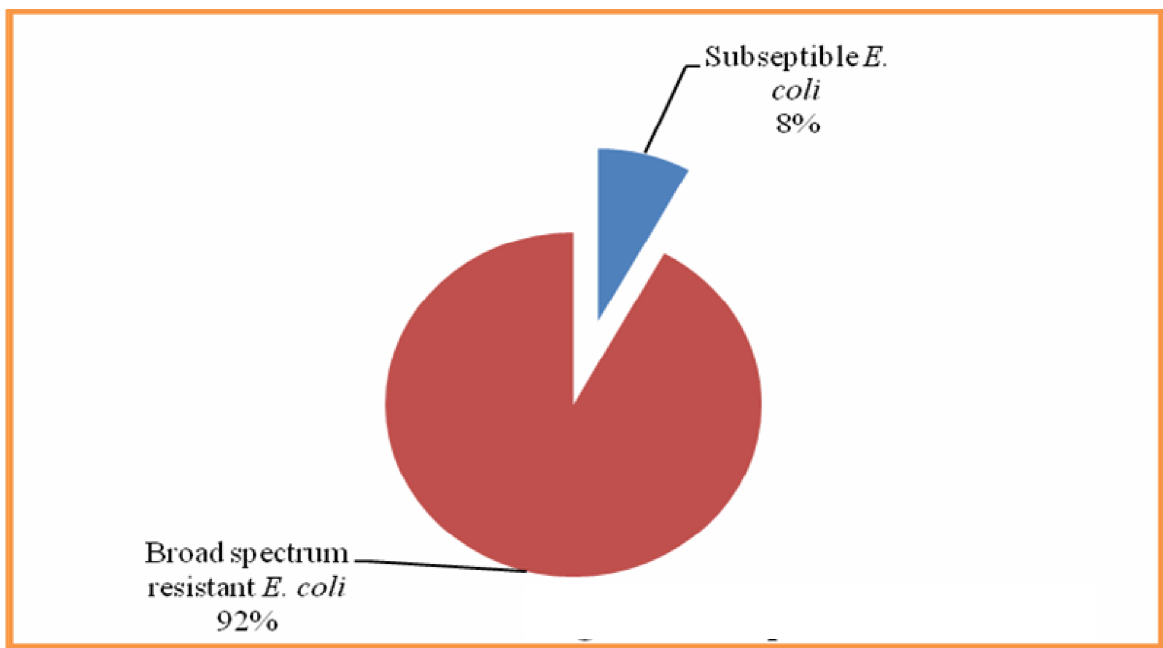


Plate.1 Antibiotic Susceptibility Testing

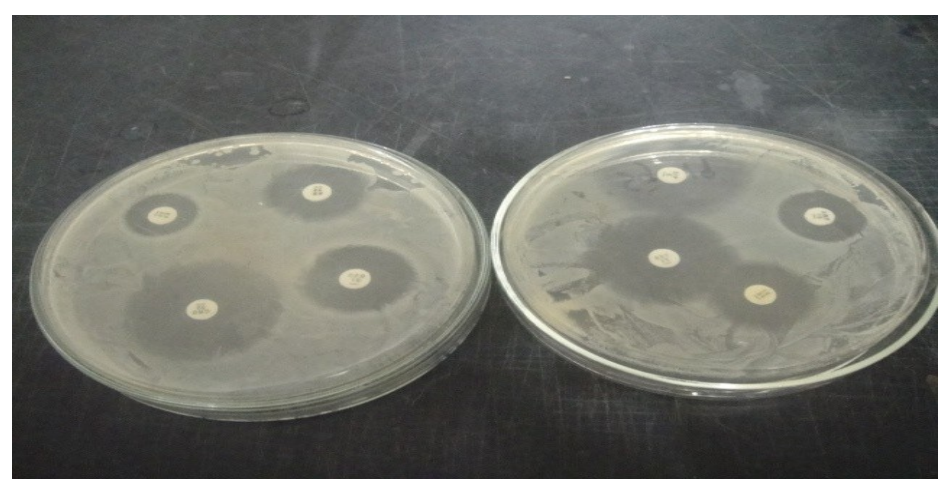

In conclusion, the presence of $E$. coli in 'zoborodo' provides undeniable evidence of the poor microbiological quality of the sorrel drink. Contamination of food by enteric pathogens can occur from the farm if human sewage is used to fertilize the soils or if sewage water is used to irrigate the plant, worst still as these pathogens exhibit resistance to commonly used antibiotics. Such risks are further increased if the food or drink is mishandled during processing and preparations where pathogens could multiply exponentially under favourable conditions (Nyenje et al., 2012). It is mandatory that foods must be free from contaminants as much as possible. The presence of E.coli, S. aureus and/or B.cereus demonstrates a potential health risk as these organisms are pathogenic and have been implicated in food borne diseases. Foodborne illness can be prevented by good hygiene practices (Oranusi et al., 2013).

Available data suggest that food can contribute to the dissemination of resistant Enterobacteriaceae in the community. To ensure that 'zoborodo' drink is microbiologically safe, both the manipulators and the food need to be continually monitored. The commercial manufacture of 'zoborodo' drink consist of a small number of the operations, but this critical process can lead to the introduction of the microorganisms or the proliferation of those already present. Possible sources of the microbial contamination have been identified as a) unhygienic handling; b) raw material; c) inadequate cleaning of the machines used, contact surfaces, clothes and manipulators' hands and d) airborne contamination (de Sousa, 2008).

\section{References}

Adenaike, O., Olonitola, O.S., Ameh, J.B. and Whong, C.M.Z. 2013. Incidence of Extended Spectrum $\beta$-lactamase Producing Bacteria and Multidrug Resistance Strains from Processed Meat 'Suya' Sold in a University Community. International Journal of Engineering and Science 2(12) 1-6.

Ayo, J. A., Umianze, H. and Gaffa, T. 2004. Microbiological Evaluation of 'Kunun zaki' and 'Zoborodo' Drink (Beverages), Locally Produced and Sold in a Polytechnic Community in Nigeria. Nigerian Food Journal 22:119-120.

Bradford, P.A. 2001. Extended Spectrum $\beta$ lactamases in the $21^{\text {st }}$ Century: Characterization, Epidemiology and Detection of this Important Resistant Threat. Clinical Microbiological Reviews 14 (4) 933-951.

Braide, W., Oranusi, S. and PeterIkechukwu, A. I. 2012. Perspectives in the Hurdle Techniques in the Preservation of a non-alcoholic beverage, 'Zobo'. African Journal of 
Food Science Technology 3(2) 46-52.

Christopher, A.F., Hora, S. and Ali, Z. 2013. Investigation of plasmid profile, antibiotic susceptibility pattern multiple antibiotic resistance index calculation of Escherichia coli isolates obtained from different human clinical specimens at tertiary care hospital in Bareilly-India. Annals of Tropical Medicine and Public Health 6:285-289.

CLSI. Clinical and Laboratory Stardards Institute. 2008. Performance Standards for Antimicrobial Susceptibility Testing. Eighteenth Informational Supplement. M100-S18 vol. 28 no.1

de Sousa, C.P. 2008. The Impact of Food Manufacturing Practices on Foodborne Diseases. Brazilian Archives of Biology and Technology 51:4.

Gaetti-Jardim, E. C., Marqueti, A.C., Favereni, L.P. and Gaetti-Jardim, E. 2010. Antimicrobial resistance of aerobes and facultative anaerobes isolated from the oral cavity. Journal of Applied Oral Science 18:6.

Hassan, S.A., Jamal, S.A. and Kamal, M. 2011. Occurrence of Multidrug Resistance and ESBL Producing E.coli causing Urinary Tract Infections. Journal of Basic Applied Sciences 7(1)39-43.

Lim, K., Yasin, R., Yeo, C., Puthucheary, S. and Thong, K. 2009. Characterization of Multi-drug Resistant ESBLProducing Escherichia coli Isolates from Hospitals in Malaysia. Journal of Biomedine and Biotechnology. Volume 2009, Article ID 165637, 10 pages.
Nwachukwu, E., Onovo, O.M. and Ezeama, C.F. 2007. Effect of Lime juice on the Bacterial quality of Zobo Drinks Locally Produced in Nigeria. Research Journal of Microbiology 2: 787-791.

Nyenje, M.E., Odjadjare, C.E., Tanih, N.F., Green, E., and Ndip, R.N. 2012. Food borne Pathogens Recovered from Ready-to-Eat Foods from Roadside Cafeterias and Retail Outlets in Alice, Eastern Cape Province, South Africa: Public Health Implications. International Journal of Environmental Research and Public Health. 9(8): 2608-2619.

Okonko, I.O., Ukut, I. O. E, Ikpoh, I. S., Nkang, A. O., Udeze, A. O., Babalola, T. A., Mejeha, O. K. and Fajobi, E. A. 2010. Assessment of Bacteriological Quality of Fresh Meats Sold in Calabar Metropolis, Nigeria. Electronic Journal of Environmental, Agricultural and Food Chemistry 9 (1):89-100.

Oranusi, S.U., Oguoma, O.I. and Agusi, E. 2013. Microbiological Quality Assessment of Foods sold in Student's Cafeterias. Global Research Journal of Microbiology 3 (1):1-7.

Tadesse, D.A, Zhao, S., Tong, E., Ayers, S., Singh, A., Bartholomew, M.J. and McDermott, P.F. 2012. Antimicrobial Drug Resistance in Escherichia coli from Humans and Food Animals, United States, 1950-2002. Emerging Infectious Diseases 18:5.

Walsh, C. (2003). Antibiotics: Actions, Origins, Resistance. ASM Press Washington D.C. Pp 42-114.

\section{How to cite this article:}

O. Adenaike, O.S. Olonitola, J.B. Ameh and C.M.Z. Whong. 2016. Incidence of Broad Spectrum Resistance in E.coli Isolated from Zoborodo sold in Samaru, Zaria. Int.J.Curr.Microbiol.App.Sci. 5(1): 796-801. ihttp://dx.doi.org/10.20546/ijcmas.2016.501.081i 